\title{
Dry matter and nutritional losses during aerobic deterioration of corn and sorghum silages as influenced by different lactic acid bacteria inocula
}

\author{
E. Tabacco, ${ }^{*}$ F. Righi, $†$ A. Quarantelli, $†$ and G. Borreani ${ }^{* 1}$ \\ *Dipartimento di Agronomia, Selvicoltura e Gestione del Territorio, University of Torino, 10095-Grugliasco (TO), Italy \\ †Dipartimento di Produzioni Animali, Biotecnologie Veterinarie, Qualità e Sicurezza degli Alimenti, Facoltà di Medicina Veterinaria, \\ University of Parma, 43126-Parma, Italy
}

\section{ABSTRACT}

The economic damage that results from aerobic deterioration of silage is a significant problem for farm profitability and feed quality. This paper quantifies the dry matter (DM) and nutritional losses that occur during the exposure of corn and sorghum silages to air over $14 \mathrm{~d}$ and assesses the possibility of enhancing the aerobic stability of silages through inoculation with lactic acid bacteria (LAB). The trial was carried out in Northern Italy on corn (50\% milk line) and grain sorghum (early dough stage) silages. The crops were ensiled in 30-L jars, without a LAB inoculant (C), with a Lactobacillus plantarum inoculum (LP), and with a Lactobacillus buchneri inoculum (LB; theoretical rate of $1 \times 10^{6} \mathrm{cfu} / \mathrm{g}$ of fresh forage). The pre-ensiled material, the silage at silo opening, and the aerobically exposed silage were analyzed for DM content, fermentative profiles, yeast and mold count, starch, crude protein, ash, fiber components, 24-h and 48-h DM digestibility and neutral detergent fiber (NDF) degradability. The yield and nutrient analysis data of the corn and sorghum silages were used as input for Milk2006 to estimate the total digestible nutrients, net energy of lactation, and milk production per $\mathrm{Mg}$ of $\mathrm{DM}$. The DM fermentation and respiration losses were also calculated. The inocula influenced the in vitro NDF digestibility at 24 $\mathrm{h}$, the net energy for lactation $\left(\mathrm{NE}_{\mathrm{L}}\right)$, and the predicted milk yield per megagram of DM, whereas the length of time of air exposure influenced DM digestibility at 24 and $48 \mathrm{~h}$, the $\mathrm{NE}_{\mathrm{L}}$, and the predicted milk yield per megagram of DM in the corn silages. The inocula only influenced the milk yield per megagram of DM and the air exposure affected the DM digestibility at $24 \mathrm{~h}$, the $\mathrm{NE}_{\mathrm{L}}$, and the milk yield per megagram of $\mathrm{DM}$ in the sorghum silages. The milk yield, after $14 \mathrm{~d}$ of air exposure, decreased to $1,442,1,418$, and $1,277 \mathrm{~kg} / \mathrm{Mg}$ of DM for C, LB, and LP corn silages, respectively,

Received June 15, 2010.

Accepted November 10, 2010.

${ }^{1}$ Corresponding author: giorgio.borreani@unito.it compared with an average value of $1,568 \mathrm{~kg}$ of silage at opening. In the sorghum silages, the milk yield, after 14 d of air exposure, decreased to 1,226, 1,278, and 1,250 $\mathrm{kg} / \mathrm{Mg}$ of DM for $\mathrm{C}, \mathrm{LB}$, and $\mathrm{LP}$, respectively. When the estimated milk yield per megagram of harvested DM of corn and sorghum silage were related to mold count, it was shown that the loss of potential milk production occurred when the mold count exceeded 4 log $\mathrm{cfu} / \mathrm{g}$ of silage, and it was almost halved when the mold count reached values greater than $8 \log \mathrm{cfu} / \mathrm{g}$ of silage. Inoculation with $L$. buchneri, at a rate of $1 \times 10^{6} \mathrm{cfu} / \mathrm{g}$ of fresh forage, enhanced the stability of the silage after exposure to air, and, consequently, contributed to maintaining the nutritional value of the harvested forage over time, for air exposure up to $7 \mathrm{~d}$.

Key words: corn silage, sorghum silage, aerobic deterioration, nutritional losses

\section{INTRODUCTION}

The aerobic deterioration of silage is a significant problem for farm profitability and feed quality throughout the world. All silages exposed to air deteriorate as a result of aerobic microbial activity during feedout. This deterioration process involves, to different extents, up to $20 \%$ of the total stored DM of corn, sorghum, and whole crop cereal farm silages, both in temperate (Borreani and Tabacco, 2009; Schmidt and Kung, 2010) and in warm climates (Huisden et al., 2009; Kang et al., 2009; Weinberg et al., 2009). A part of the efforts made to produce high yields per hectare of high-quality, whole-crop silages is cancelled out when aerobic deterioration takes place. The losses could reach $70 \%$ of the stored DM in the peripheral areas and near the sidewalls of the bunkers and are related to the depletion of the digestible carbohydrate and organic acid fractions (Bolsen et al., 1993). Silage that has spoiled because of exposure to air is undesirable, due to the lower nutritive value and to the risk of negative effects on animal performance (Kung et al., 1998), which are also connected to the proliferation of potentially pathogenic or otherwise undesirable microorganisms (Lindgren et al., 
2002) and mycotoxin synthesis (Richard et al., 2009). Whitlock et al. (2000) fed steers spoiled corn silage at different rates and reported a decrease in DM intake, OM digestibility and NDF digestibility of 7.4, 6.6, and $11.3 \%$, respectively, when only $5 \%$ of spoiled silage was included in the ration. Thus, the stability of airexposed silage is a very important factor in determining its subsequent nutritional quality and feeding value (Filya, 2004). The aerobic deterioration of silage at the farm level can be contained in several ways (e.g., silage management and chemical or microbial additives; Ranjit and Kung, 2000; Borreani et al., 2007). The stability of silages against aerobic deterioration can vary from well-fermented homolactic silages, which tend to spoil faster, to heterofermentative silages fermented by Lactobacillus buchneri, which could improve the stability of silages via the anaerobic degradation of lactic acid to acetic acid (Oude Elferink et al., 2001; Kleinschmit and Kung, 2006). Prolonged exposure to oxygen (up to 20 d) can occur before the removal of silages from the silo because oxygen can penetrate the silage mass (Kung et al., 1998; Weinberg et al., 2009). Thus, to better understand the economic damage related to aerobic deterioration of silage, it appears to be important to quantify the DM and nutritional losses that occur during air exposure and to assess the possibility of enhancing the aerobic stability of silages by means of lactic acid bacteria (LAB) inoculation.

The purpose of the present study was to assess the effect of a homolactic and a heterolactic LAB inoculum on the DM and nutritive losses after 0, 7, and $14 \mathrm{~d}$ of air exposure of corn and sorghum silages.

\section{MATERIALS AND METHODS}

\section{Crop and Ensiling}

The trial was carried out at the experimental farm of the University of Turin in the western Po Plain, northern Italy $\left(44^{\circ} 50^{\prime} \mathrm{N}, 7^{\circ} 40^{\prime} \mathrm{E}\right.$, altitude $232 \mathrm{~m}$ above sea level) in 2005 on corn (Zea mays L.) and grain sorghum (Sorghum bicolor L.), grown for ensiling. The whole corn crop was harvested at around the $50 \%$ milkline stage $(35.2 \%$ of DM), and the sorghum at the early dough stage ( $40.4 \%$ of DM), and they were chopped to a 10-mm theoretical length using a conventional forage harvester. Both the corn and sorghum forages were ensiled without a LAB inoculant $(\mathbf{C})$, with a Lactobacillus plantarum inoculum (LP; Lactosil, CSL, Lodi, Italy), and with a L. buchneri inoculum (LB; strain NCIMB 40788, Lalsil Fresh, Lallemand SA, Toulouse, France). Both inocula were applied at a theoretical rate of 1 $\times 10^{6} \mathrm{cfu}$ of bacteria per $1 \mathrm{~g}$ of fresh forage, with 4 replications for each treatment. The inoculants were diluted in deionized water and applied using a hand sprayer $(1.5 \mathrm{~L})$ at the rate of $2 \mathrm{~mL} / \mathrm{kg}$ of forage. The fresh corn and sorghum forages were sampled before ensiling before the inoculum was applied. The treated forages were ensiled (about $18 \mathrm{~kg}$ of fresh forage) in $30-\mathrm{L}$ plastic jars equipped with a lid that only enables gas release. The forages were packed into experimental silos to achieve a final packing density of $198 \pm 8.6$ $\mathrm{kg}$ of $\mathrm{DM} / \mathrm{m}^{3}$ and of $228 \pm 9.9 \mathrm{~kg}$ of $\mathrm{DM} / \mathrm{m}^{3}$, for corn and sorghum, respectively. The silos were conserved at $20^{\circ} \mathrm{C}$ and opened after 90 and $93 \mathrm{~d}$ for the corn and sorghum silages, respectively. Each silo was weighed, and contents were mixed thoroughly and subsampled to determine the DM content (3 replicates), the fermentation profile (2 replicates), and the microbiological counts (2 replicates). The silages were subjected to an aerobic stability test. Aerobic stability was determined by monitoring temperature increases due to microbial activity of the samples exposed to air. Three kilograms from each silo was allowed to aerobically deteriorate at room temperature $\left(20 \pm 1.6^{\circ} \mathrm{C}\right)$ in 20 -L polystyrene boxes for $14 \mathrm{~d}$. A single layer of aluminum cooking foil was placed over each box to prevent drying and dust contamination, but also to allow air to penetrate. The room temperature and the temperature from each silage were measured each hour by a mini temperature logger (Escort Intelligent Mini, Escort Data Logging Systems Ltd., Auckland, New Zealand). The silages were not disturbed throughout the recording of the temperatures. The difference between the silage temperature and ambient temperature was defined as dT. Aerobic stability was defined as the number of hours the silage remained stable before rising more than $2^{\circ} \mathrm{C}$ above room temperature (Ranjit and Kung, 2000). The hourly cumulated temperature above the ambient temperature during air exposure of the silages was calculated for each treatment until the $14 \mathrm{~d}$ of air exposure. Silages were sampled after 0,7 , and $14 \mathrm{~d}$ of aerobic exposure to quantify the microbial and chemical changes during exposure to air.

\section{Chemical and Microbial Analyses}

The pre-ensiled material, the silage at silo opening, and the aerobically exposed silage were split into 2 subsamples. One subsample was oven-dried at $60^{\circ} \mathrm{C}$ for $72 \mathrm{~h}$ to determine the DM content, and then air equilibrated, weighed, and ground in a Cyclotec mill (Tecator, Herndon, VA) to pass a 1-mm screen. The dried pre-ensiled and silage samples were analyzed for total nitrogen (TN) content, according to the Dumas method, using a nitrogen analyzer Micro-N (Elementar, Hanau, Germany), for $\mathrm{CP}$ (total $\mathrm{N} \times 6.25$ ) content, for ash content by ignition to $550^{\circ} \mathrm{C}$, for water-soluble 
carbohydrates (WSC; (Deriaz, 1961) content, for NDF content, using heat-stable amylase (A3306, Sigma Chemical Co., St. Louis, MO), ADF content, and acid detergent lignin (ADL) content according to Robertson and Van Soest (1981), for ether extract (EE) concentration by ether extraction, and for starch concentration according to the methods of the Association of Official Analytical Chemists (2005), using a K-AMYL assay kit (Megazyme International, Bray, Ireland). In vitro NDF digestibility (NDF-D) was measured as described by Goering and Van Soest (1970). Forage subsamples of pre-ensiled material, and silages were weighed $(0.5 \mathrm{~g})$ in 100-mL flasks (Schott Duran, Wertheim/Main, Germany). A medium, composed of a buffer, a macromineral solution, a micromineral solution, and resazurin as the redox state indicator of the system were introduced into the flasks. A reducing solution was added to create an anaerobic environment. The flasks were then introduced into a water bath and purged with $\mathrm{CO}_{2}$ to obtain complete anaerobiosis. Rumen fluid was collected from a dry cow fed $2 \mathrm{~kg}$ of concentrate per day and given ad libitum access to grass/alfalfa mixed hay ( $55 \% \mathrm{NDF}$; $14 \% \mathrm{CP})$. It was then stirred, filtered through cheesecloth, and inoculated into each flask to start sample fermentation. Subsamples were incubated for 24 or 48 $\mathrm{h}$ at 39.5 to $40^{\circ} \mathrm{C}$. Four replicates were incubated per treatment for each incubation period. After incubation, aNDF was determined on each fermented subsample using a Raw Fiber Extractor (FIWE, VELP Scientifica, Usmate Velate, Italy). The content of each flask was introduced into raw fiber extractor tubes, boiled in a neutral detergent solution that included heat-stable amylase (Number A3306; Sigma Chemical Co.) and filtered through crucibles (Robu Glass Filter-ROBU H3, Borosilicate 3.3, 30 mL-Por. 2, Hattert, Germany). The residuals were then rinsed 3 times with boiling water, dried overnight at $103^{\circ} \mathrm{C}$ and weighed to calculate NDF-D at 24 and $48 \mathrm{~h}$.

The in vitro DM digestibility (DM-D) digestion phase was performed as described for the NDF-D determination. After incubation, the content of the flask was filtered through crucibles (Robu Glass Filter, Por. 2 ) and rinsed 3 times with boiling water to remove the digested substrates and bacteria, then dried overnight at $103^{\circ} \mathrm{C}$ and weighed to calculate DM-D at 24 and 48 h.

The second subsample was stored as a wet sample at $-30^{\circ} \mathrm{C}$. Wet samples were extracted using a Stomacher blender (Seward Ltd., West Sussex, UK) for 4 min in distilled water at a water-to-sample material (fresh weight) ratio of 1:10 or in $0.1 \mathrm{~N} \mathrm{H}_{2} \mathrm{SO}_{4}$ at an acid-to-sample material (fresh weight) ratio of 1:5. The ammonia nitrogen $\left(\mathrm{NH}_{3}-\mathrm{N}\right)$ content, determined using a specific electrode, was quantified in the water extract.
The lactic and monocarboxylic acids (acetic, propionic, and butyric acids) were determined by HPLC in the acid extract (Canale et al., 1984). The duplicates were averaged and the 4 means (one for each silo) were considered as 4 observations in the statistical analysis.

The weight losses due to fermentation were calculated as the difference between the weight of the plant material placed in each plastic jar at ensiling and the weight of the silage at the end of conservation, corrected for the DM content of forage and its respective silage. The DM losses during the air exposure of the silages were determined as the dry weight differences between 2 sampling periods (i.e., 0 to $7 \mathrm{~d}$ of air exposure and 7 to $14 \mathrm{~d}$ of air exposure).

The yeast and cfu were counted using the pour plate technique with $40.0 \mathrm{~g} / \mathrm{L}$ of yeast extract glucose chloramphenicol agar (YGC agar, Difco, West Molesey, Surrey, UK) after incubation at $25^{\circ} \mathrm{C}$ for 3 and $5 \mathrm{~d}$ for yeast and mold, respectively.

The yield and nutrient analysis data of the corn and sorghum silages were used as input for Milk2006 (Shaver et al., 2006) to estimate the total digestible nutrients (TDN1x), net energy of lactation at $3 \times$ maintenance (NEL-3x), and the milk production per $\mathrm{Mg}$ of DM $(\mathrm{kg} /$ $\mathrm{Mg})$, and per acre $(\mathrm{kg} / \mathrm{acre})$. The latter was converted into the metric system $(\mathrm{kg}$ milk/ha) for presentation purposes. The NDF-D at $48 \mathrm{~h}$ of incubation was used as the NDF digestibility value. Because the DM content of the silage decreased with aerobic deterioration to lower values than $30 \%$ for all of the estimations of milk production from the silage samples, the DM content was assumed to be equal to the average value of the silage at silo opening (34.4 and $39.5 \%$ for corn and sorghum, respectively). This was done to avoid the correction for starch digestibility, which Milk2006 automatically does according to the variation in the DM content of the sample.

\section{Statistical Analyses}

All of the microbial counts were $\log _{10}$-transformed to obtain log-normal distributed data and presented on a wet weight basis. The values below the detection level (detection levels: 10 yeast/g and $10 \mathrm{mold} / \mathrm{g}$ ) were assigned a value corresponding to half of the detection level (i.e., 5 yeast $/ \mathrm{g}$ and $5 \mathrm{mold} / \mathrm{g}$ ) to calculate the averages. The fermentative characteristics, microbial counts, pH, dry weight losses, and hours of aerobic stability of the silages at silo opening were analyzed for their statistical significance via ANOVA of the Statistical Package for Social Science (version 16, SPSS Inc., Chicago, IL). Any significant differences between the means were identified from the $P$-values of the ANOVA and the effects were considered significant at $P<0.05$. 
Table 1. Dry matter and chemical composition (DM basis) of freshly chopped whole-plant corn and sorghum before ensiling

\begin{tabular}{|c|c|c|}
\hline Item & Corn & Sorghum \\
\hline DM yield (Mg/ha) & 20.3 & 13.3 \\
\hline Development stage & $1 / 2 \mathrm{ML}^{1}$ & Dough \\
\hline DM (\%) & $35.2 \pm 0.36$ & $40.4 \pm 0.70$ \\
\hline Starch (\% of DM) & $30.8 \pm 0.41$ & $25.9 \pm 0.96$ \\
\hline $\mathrm{WSC}^{2}(\%$ of $\mathrm{DM})$ & $12.1 \pm 0.32$ & $9.0 \pm 0.43$ \\
\hline $\mathrm{CP}(\%$ of $\mathrm{DM})$ & $7.51 \pm 0.10$ & $5.68 \pm 0.13$ \\
\hline Ether extract (\% of DM) & $2.43 \pm 0.08$ & $3.15 \pm 0.07$ \\
\hline NDF (\% of DM) & $44.3 \pm 0.93$ & $45.9 \pm 0.82$ \\
\hline $\mathrm{ADF}(\%$ of $\mathrm{DM})$ & $21.7 \pm 0.44$ & $23.2 \pm 0.47$ \\
\hline $\mathrm{ADL}^{3}(\%$ of $\mathrm{DM})$ & $2.73 \pm 0.06$ & $3.21 \pm 0.08$ \\
\hline Hemicelluloses ${ }^{4}(\%$ of DM) & $22.5 \pm 0.59$ & $22.7 \pm 0.40$ \\
\hline Ash (\% of DM) & $3.20 \pm 0.08$ & $5.89 \pm 0.12$ \\
\hline NDF-D 54 h ( $\%$ of DM) & $41.6 \pm 0.85$ & $43.9 \pm 0.58$ \\
\hline NDF-D $48 \mathrm{~h}(\%$ of DM) & $59.9 \pm 2.74$ & $53.6 \pm 2.14$ \\
\hline DM-D ${ }^{6} 24 \mathrm{~h}(\%$ of DM) & $54.5 \pm 1.14$ & $57.8 \pm 1.18$ \\
\hline DM-D $48 \mathrm{~h}(\%$ of DM) & $66.2 \pm 1.20$ & $65.9 \pm 0.64$ \\
\hline $\mathrm{NE}_{\mathrm{L}}^{7}(\mathrm{Mcal} / \mathrm{kg})$ & $1.60 \pm 0.013$ & $1.52 \pm 0.022$ \\
\hline Milk per $\mathrm{Mg}^{7}(\mathrm{~kg} / \mathrm{Mg} \mathrm{DM})$ & $1,603 \pm 23$ & $1,491 \pm 36$ \\
\hline Milk per hectare ${ }^{7^{\prime}}(\mathrm{kg} / \mathrm{ha})$ & $29,021 \pm 422$ & $17,681 \pm 421$ \\
\hline
\end{tabular}

${ }^{1}$ Milk line.

${ }^{2}$ Water-soluble carbohydrates.

${ }^{3}$ Acid detergent lignin.

${ }^{4}$ Hemicellulose $=$ NDF - ADF .

${ }^{5}$ In vitro NDF digestibility.

${ }^{6}$ In vitro DM digestibility.

${ }^{7}$ Estimations were made with MILK2006, using NDF-D $48 \mathrm{~h}$ as the default value.

When the calculated values of $\mathrm{F}$ were significant, the Tukey range test $(P<0.05)$ was used to interpret any significant differences among the mean values.

The chemical compositional data were analyzed with the GLM procedure according to the model for a $3 \times 3$ factorial treatment design:

$$
Y_{i j}=\mu+I_{i}+T_{j}+(I \times T)_{i j}+e_{i j}
$$

where $Y_{i j}=$ dependent continuous variable, $\mu$ = overall mean; $I_{i}=$ effect of inoculation; $T_{j}=$ effect of time of air exposure; $(I \times T)_{i j}=$ effect of interaction between the inoculation and the time of air exposure; and $e_{i j}$ $=$ error term. Significance was defined at a 0.05 probability level.

The pooled data of milk per megagram of original DM, collected from silages at silo opening and from aerobically deteriorated silages during air exposure, were regressed on mold count and hourly cumulated temperature above the ambient temperature during air exposure (TCUM), as the independent variables. Linear and quadratic regressions were compared using the stepwise selection procedure of the SPSS to select the best regression model at $P<0.05$. The best equation was selected using the coefficient of determination and root mean square error (RMSE). All of the reported coefficients of determination $\left(\mathrm{R}^{2}\right)$ were adjusted for degrees of freedom.

\section{RESULTS}

The chemical composition of the corn and sorghum forages before ensiling are shown in Table 1. The corn harvested at the $50 \%$ milk line was $35.2 \%$ of DM, $30.8 \%$ of starch, $7.51 \%$ of CP, and contained $12.1 \%$ of WSC. The sorghum crop presented slightly higher DM and a lower starch concentration than corn and a WSC content of around 9.0\% DM. The NDF-D at $24 \mathrm{~h}$ was 41.6 and $43.9 \%$ and the NDF-D at $48 \mathrm{~h}$ was 59.9 and $53.6 \%$ for the corn and sorghum, respectively. The calculated milk per $\mathrm{Mg}$ of DM was 1,603 and $1,491 \mathrm{~kg} / \mathrm{Mg}$ of $\mathrm{DM}$ for the corn and sorghum, respectively.

The fermentation quality and microbial composition of the corn and sorghum silages after $90 \mathrm{~d}$ of conservation are shown in Table 2. All of the silages were well fermented. The primary fermentation acids were lactic and acetic acids, with traces of propionic acid, whereas butyric acid was below the detection limit $(<0.01 \%$ of $\mathrm{DM}$ ) in all of the silages. The inoculation of corn and sorghum forage with $L$. buchneri led to silages with higher $\mathrm{pH}$ measurements $(P<0.001)$, greater concentrations of acetic acid $(P<0.001)$, lower concentrations of lactic acid $(P<0.001)$, and greater aerobic stability compared with those of the $\mathrm{C}$ and LP silages. The fermentation DM losses ranged from 2.4 to $3.4 \%$ in the corn silage and from 2.0 to $2.8 \%$ in the sorghum silages (Figure 1).

The chemical composition of the corn silages at opening and after 7 and $14 \mathrm{~d}$ of air exposure are reported in Table 3. The inoculum treatment influenced the CP and ADL concentrations, whereas the time of air exposure influenced all of the parameters, except the EE and hemicelluloses. The composition of sorghum silages was affected by the inoculum for most of the parameters, except the EE, NDF, and hemicelluloses, whereas the time of air exposure influenced all of the studied parameters (Table 4). The ash, CP, NDF, ADF, ADL, and hemicelluloses contents increased with time of air exposure, whereas starch concentration decreased after $14 \mathrm{~d}$ of air exposure, for both the corn and sorghum silages.

The DM and NDF degradability at 24 and $48 \mathrm{~h}$ and the estimated milk yield are reported in Tables 5 and 6 for the corn and sorghum silages, respectively. The inocula influenced the NDF-D at $24 \mathrm{~h}$, the $\mathrm{NE}_{\mathrm{L}}$, and the milk yield per megagram of DM, whereas the time of air exposure influenced the DM digestibility at 24 and $48 \mathrm{~h}$, the $\mathrm{NE}_{\mathrm{L}}$, and the milk yield per megagram of $\mathrm{DM}$ in the corn silages. The inocula only influenced the milk yield per megagram of DM and the time of air exposure 
Table 2. Fermentation quality of the uninoculated silage (C) and inoculated with Lactobacillus buchneri (LB) or with Lactobacillus plantarum (LP) corn and sorghum silages after $90 \mathrm{~d}$ of conservation

\begin{tabular}{|c|c|c|c|c|c|c|c|c|c|c|}
\hline \multirow[b]{2}{*}{ Treatment } & \multicolumn{5}{|c|}{ Corn } & \multicolumn{5}{|c|}{ Sorghum } \\
\hline & $\mathrm{C}$ & $\mathrm{LB}$ & LP & SE & $P$-value & $\mathrm{C}$ & LB & LP & SE & $P$-value \\
\hline $\mathrm{pH}$ & $3.57^{\mathrm{b}}$ & $3.74^{\mathrm{a}}$ & $3.57^{\mathrm{b}}$ & 0.02 & $<0.001$ & $3.84^{\mathrm{b}}$ & $3.95^{\mathrm{a}}$ & $3.78^{\mathrm{b}}$ & 0.02 & 0.004 \\
\hline Lactic acid (\% of DM) & $5.64^{\mathrm{a}}$ & $4.07^{\mathrm{b}}$ & $5.91^{\mathrm{a}}$ & 0.27 & $<0.001$ & $4.58^{\mathrm{a}}$ & $3.85^{\mathrm{b}}$ & $4.90^{\mathrm{a}}$ & 0.17 & 0.011 \\
\hline Acetic acid (\% of DM) & $1.23^{\mathrm{b}}$ & $2.92^{\mathrm{a}}$ & $1.19^{\mathrm{b}}$ & 0.25 & $<0.001$ & $0.94^{\mathrm{b}}$ & $1.90^{\mathrm{a}}$ & $1.06^{\mathrm{b}}$ & 0.13 & $<0.001$ \\
\hline $\mathrm{NH}_{3}-\mathrm{N}\left(\%\right.$ of $\left.\mathrm{TN}^{1}\right)$ & 5.50 & 6.10 & 5.07 & 0.22 & 0.149 & 4.60 & 4.75 & 5.23 & 0.18 & 0.343 \\
\hline Aerobic stability (h) & 39 & 307 & 43 & - & - & 43 & 289 & 45 & - & - \\
\hline
\end{tabular}

${ }^{\mathrm{a}, \mathrm{b}}$ Mean values within column having different superscripts differ $(P<0.05)$.

${ }^{1}$ Total nitrogen.

affected the DM digestibility at $24 \mathrm{~h}$, the $\mathrm{NE}_{\mathrm{L}}$, and the milk yield per megagram of DM in the sorghum silages. The predicted milk yield, after $14 \mathrm{~d}$ of air exposure, decreased to $1,442,1,418$, and $1,277 \mathrm{~kg} / \mathrm{Mg}$ of $\mathrm{DM}$ for the $\mathrm{C}, \mathrm{LB}$, and LP corn silages, respectively, compared with an average value of $1,568 \mathrm{~kg}$ of silage at opening $(0$
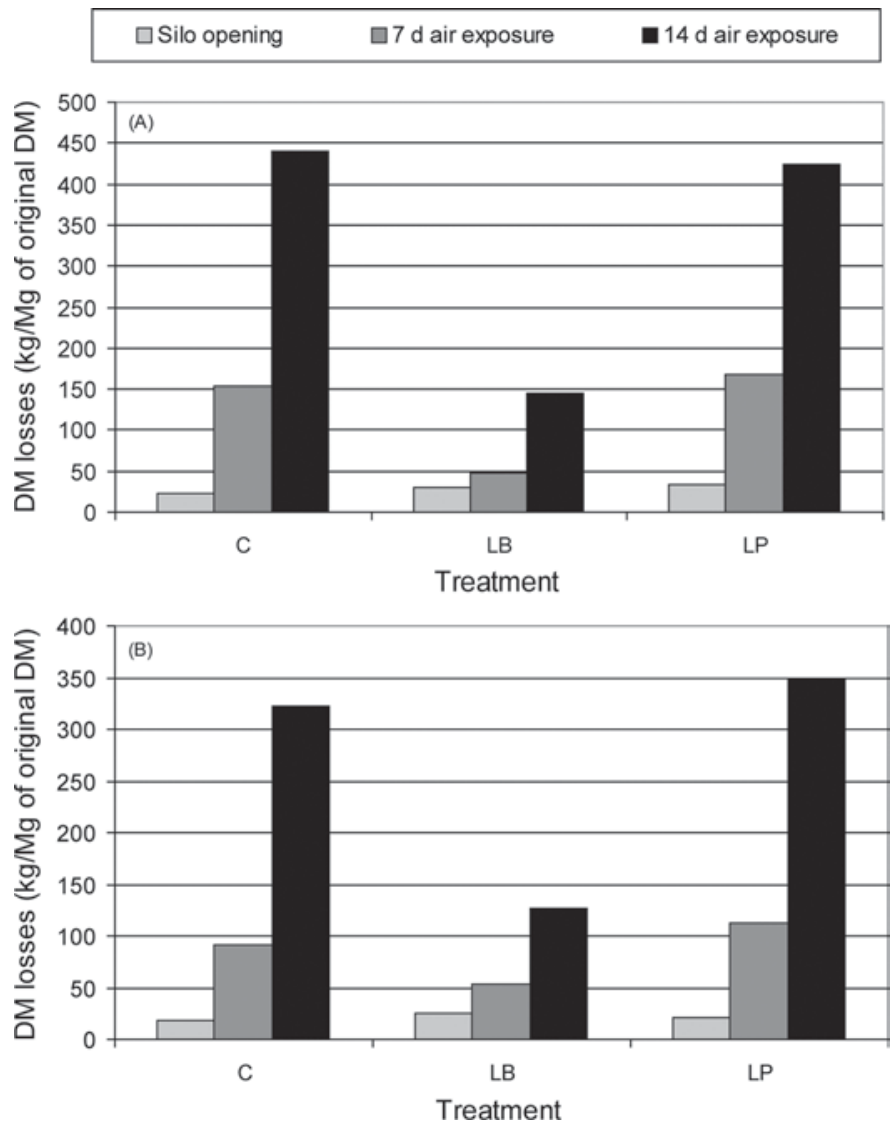

Figure 1. Dry matter fermentation and respiration losses of uninoculated (C), inoculated with Lactobacillus plantarum (LP), and inoculated with Lactobacillus buchneri (LB) corn (A) and sorghum (B) silages at silo opening and after 7 and $14 \mathrm{~d}$ of air exposure $(\mathrm{kg}$ of original ensiled DM). d). In the sorghum silages, the milk yield, after $14 \mathrm{~d}$ of air exposure, decreased to $1,226,1,278$, and $1,250 \mathrm{~kg} /$ $\mathrm{Mg}$ of DM for C, LB, and LP, respectively.

The DM fermentation and respiration losses that occurred during ensiling and after air exposure of the silages are reported in Figure 1. The fermentation losses at silo opening were below $50 \mathrm{~kg} / \mathrm{Mg}$ of original $\mathrm{DM}$ for both the corn and sorghum silages, irrespective of the inoculation treatment. After $7 \mathrm{~d}$ of air exposure, the losses increased to values of around $150 \mathrm{~kg} / \mathrm{Mg}$ in the $\mathrm{C}$ and LP treatments for the corn silage, and around $100 \mathrm{~kg} / \mathrm{Mg}$ in the $\mathrm{C}$ and LP treatments in the sorghum silage. The LB treatment maintained the losses after 7 $\mathrm{d}$ of air exposure at around $50 \mathrm{~kg} / \mathrm{Mg}$ in both the corn and sorghum silages. After $14 \mathrm{~d}$ of air exposure, the DM losses dramatically increased in the $\mathrm{C}$ and LP treatments, with values that were always greater than 300 $\mathrm{kg} / \mathrm{Mg}$ of the original DM, whereas the LB treatment maintained losses below $150 \mathrm{~kg} / \mathrm{Mg}$ for both crops.

The estimated milk yields per megagram of original DM harvested in the field are reported in Figures 2 and 3 for the corn and sorghum silages, respectively. The interactive effect of DM losses and nutritive losses due to fermentation during conservation and to respiration during air exposure decreased the potential milk yield per megagram of harvested corn to values of around $800 \mathrm{~kg}$ in the $\mathrm{C}$ and LP treatments and to around 1,200 $\mathrm{kg}$ in the LB treatment after $14 \mathrm{~d}$ of air exposure. In the sorghum silage, the milk yield per megagram of original DM decreased from a mean value of $1,438 \mathrm{~kg}$ at silo opening to values of around $800 \mathrm{~kg}$ in the $\mathrm{C}$ and $\mathrm{LP}$ treatments and to around $1,100 \mathrm{~kg}$ in the $\mathrm{LB}$ treatment after $14 \mathrm{~d}$ of air exposure.

The milk per $\mathrm{Mg}$ of original corn and sorghum herbage at harvesting related to the mold count and TCUM are reported in Figure 4. The decrease in milk per megagram of original DM during air exposure of the silage was related to the mold count with an $\mathrm{R}^{2}$ of 0.746 
Table 3. Chemical composition of uninoculated (C), inoculated with Lactobacillus plantarum (LP), and inoculated with Lactobacillus buchneri (LB) corn silages after 0,7 , and $14 \mathrm{~d}$ of air exposure (\% of DM unless stated otherwise)

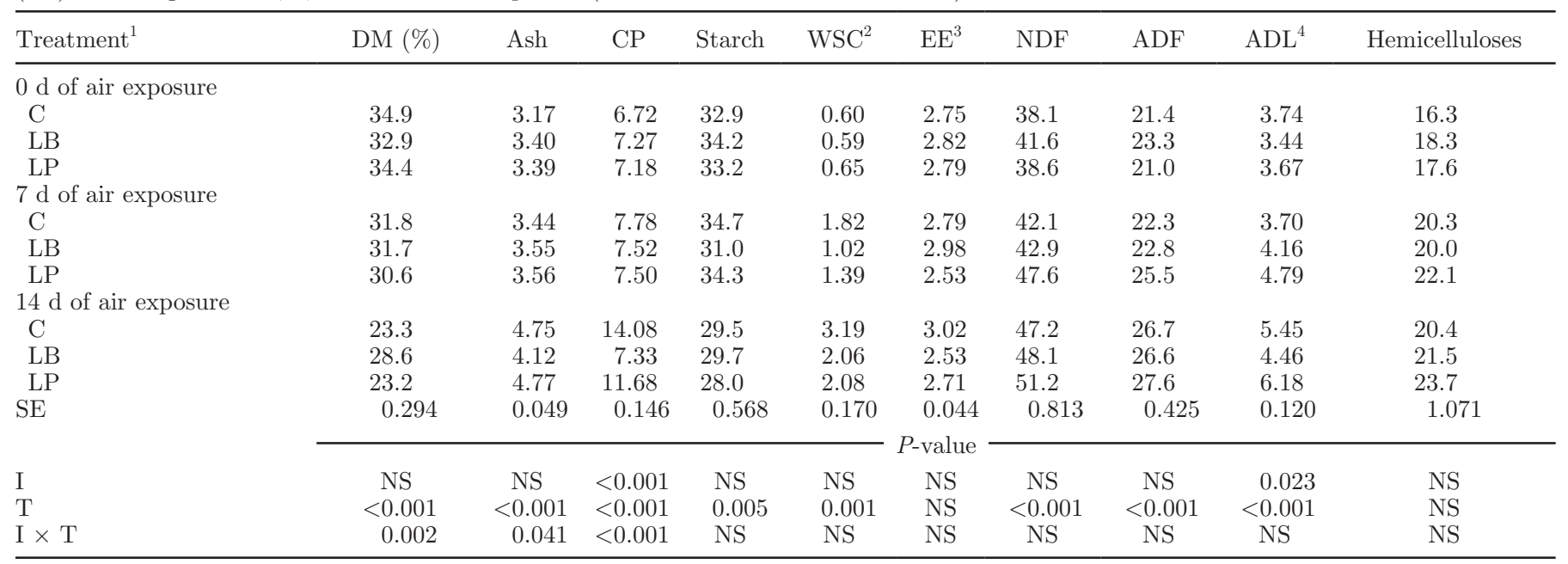

${ }^{1} \mathrm{I}=$ inoculum effect; $\mathrm{T}=$ air exposure time effect; $\mathrm{I} \times \mathrm{T}=$ interaction effect.

${ }^{2}$ Water-soluble carbohydrates.

${ }^{3}$ Ether extract.

${ }^{4}$ Acid detergent lignin.

for the corn and of 0.800 for the sorghum silages (Table 7, equations 1 and 2), whereas it showed an $\mathrm{R}^{2}$ of 0.771 and of 0.741 for the corn and sorghum, respectively, when the hourly accumulated temperature during air exposure was considered (Table 7 , equations 3 and 4 ).

\section{DISCUSSION}

The research here reported was designed to evaluate the efficacy of $L$. buchneri as a silage inoculant to enhance aerobic stability and to limit the negative effects of aerobic deterioration on the nutritional value of whole plant corn and sorghum silages.

Inoculation with $L$. buchneri at ensiling is commonly suggested today to partially prevent aerobic deterioration at the farm level (Mari et al., 2009). However, because $L$. buchneri has been associated with increased DM losses during the anaerobic conservation phase, a second objective of this paper was to evaluate whether an improvement in aerobic stability during feeding could

Table 4. Chemical composition of uninoculated (C), inoculated with Lactobacillus plantarum (LP), and inoculated with Lactobacillus buchneri (LB) sorghum silages after 0,7 , and $14 \mathrm{~d}$ of air exposure (\% of DM unless stated otherwise)

\begin{tabular}{|c|c|c|c|c|c|c|c|c|c|c|}
\hline Treatment $^{1}$ & DM $(\%)$ & Ash & $\mathrm{CP}$ & Starch & $\mathrm{WSC}^{2}$ & $\mathrm{EE}^{3}$ & NDF & $\mathrm{ADF}$ & $\mathrm{ADL}^{4}$ & Hemicelluloses \\
\hline \multicolumn{11}{|c|}{$0 \mathrm{~d}$ of air exposure } \\
\hline $\mathrm{C}$ & 41.2 & 5.40 & 5.27 & 31.3 & 0.83 & 3.38 & 40.2 & 21.3 & 3.03 & 18.9 \\
\hline LB & 39.6 & 5.71 & 5.58 & 33.0 & 0.63 & 3.49 & 40.7 & 22.1 & 3.16 & 18.5 \\
\hline LP & 38.7 & 5.78 & 5.29 & 30.8 & 0.95 & 3.39 & 41.1 & 22.8 & 3.26 & 18.2 \\
\hline \multicolumn{11}{|c|}{$7 \mathrm{~d}$ of air exposure } \\
\hline $\mathrm{C}$ & 38.0 & 6.23 & 6.16 & 32.7 & 1.26 & 3.29 & 43.9 & 24.4 & 3.72 & 19.5 \\
\hline LB & 38.4 & 6.12 & 5.97 & 30.4 & 0.85 & 3.42 & 43.2 & 23.2 & 3.39 & 20.1 \\
\hline LP & 36.4 & 6.54 & 6.32 & 31.0 & 1.43 & 3.31 & 45.1 & 25.4 & 3.70 & 19.8 \\
\hline \multicolumn{11}{|c|}{$14 \mathrm{~d}$ of air exposure } \\
\hline $\mathrm{C}$ & 30.9 & 7.71 & 8.63 & 25.3 & 3.26 & 3.64 & 49.6 & 29.1 & 5.19 & 20.5 \\
\hline LB & 36.9 & 6.22 & 6.09 & 24.7 & 0.87 & 3.30 & 46.3 & 25.3 & 3.56 & 21.0 \\
\hline LP & 29.5 & 7.98 & 8.49 & 20.2 & 2.63 & 3.86 & 50.3 & 30.1 & 4.98 & 20.3 \\
\hline $\mathrm{SE}$ & 0.331 & 0.053 & 0.119 & 0.396 & 0.126 & 0.033 & 0.431 & 0.235 & 0.070 & 0.292 \\
\hline $\mathrm{I}^{1}$ & 0.002 & $<0.001$ & 0.012 & 0.038 & 0.006 & NS & NS & 0.001 & 0.002 & $\mathrm{NS}$ \\
\hline $\mathrm{T}$ & $<0.001$ & $<0.001$ & $<0.001$ & $<0.001$ & $<0.001$ & 0.013 & $<0.001$ & $<0.001$ & $<0.001$ & 0.027 \\
\hline $\mathrm{I} \times \mathrm{T}$ & 0.008 & $<0.001$ & 0.002 & NS & NS & 0.015 & NS & 0.025 & 0.003 & NS \\
\hline
\end{tabular}

${ }^{1} \mathrm{I}=$ inoculum effect; $\mathrm{T}=$ air exposure time effect; $\mathrm{I} \times \mathrm{T}=$ interaction effect.

${ }^{2}$ Water-soluble carbohydrates.

${ }^{3}$ Ether extract.

${ }^{4}$ Acid detergent lignin. 
Table 5. Digestibility and NDF degradability at $24 \mathrm{~h}$ and $48 \mathrm{~h}$ and estimated milk yield of uninoculated (C), inoculated with Lactobacillus plantarum (LP), and inoculated with Lactobacillus buchneri (LB) corn silages after 0, 7, and $14 \mathrm{~d}$ of air exposure (DM basis)

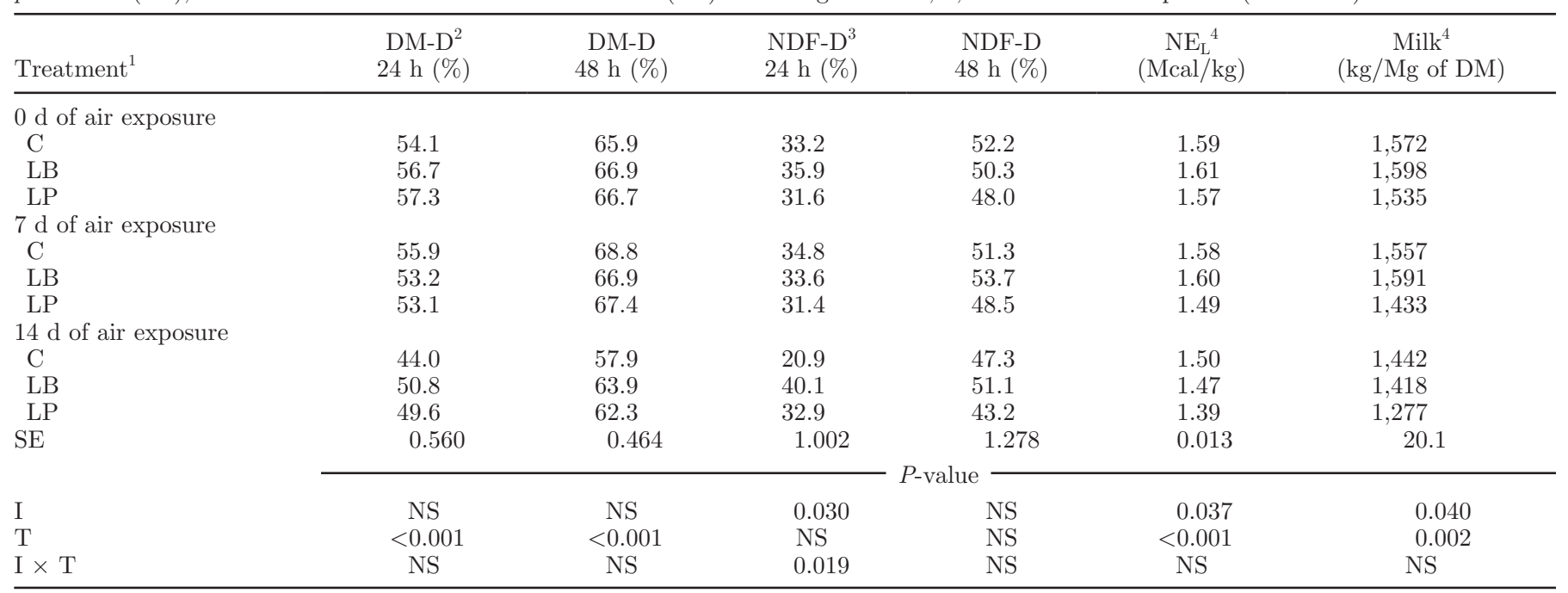

${ }^{1} \mathrm{I}=$ inoculum effect; $\mathrm{T}=$ air exposure time effect; $\mathrm{I} \times \mathrm{T}=$ interaction effect.

${ }^{2}$ In vitro DM digestibility.

${ }^{3}$ In vitro NDF digestibility.

${ }^{4}$ Estimations were made with MILK2006, using NDF-D $48 \mathrm{~h}$ as the default value.

be beneficial, by making the small losses of DM that incur from heterofermentation less important (Kung and Ranjit, 2001).

In this experiment, the chemical composition, DM digestibility, and NDF-D at 24 and $48 \mathrm{~h}$ of freshly chopped whole-plant corn and sorghum before ensiling were within the expected range for corn and sorghum grown in Italy (Borreani and Tabacco, 2007). Both crops showed the potential of producing an estimated milk yield of about 1,600 and 1,490 $\mathrm{kg}$ per $\mathrm{Mg}$ of $\mathrm{DM}$ for corn and sorghum, respectively. These values are consistent with the values reported by Kung et al. (2008), Lauer et al. (2009), and Marsalis et al. (2009), concerning whole plant corn and sorghum. Many studies have

Table 6. Dry matter digestibility and NDF degradability at $24 \mathrm{~h}$ and $48 \mathrm{~h}$ and estimated milk yield of uninoculated (C), inoculated with Lactobacillus plantarum (LP), and inoculated with Lactobacillus buchneri (LB) sorghum silages after 0, 7, and $14 \mathrm{~d}$ of air exposure (DM basis)

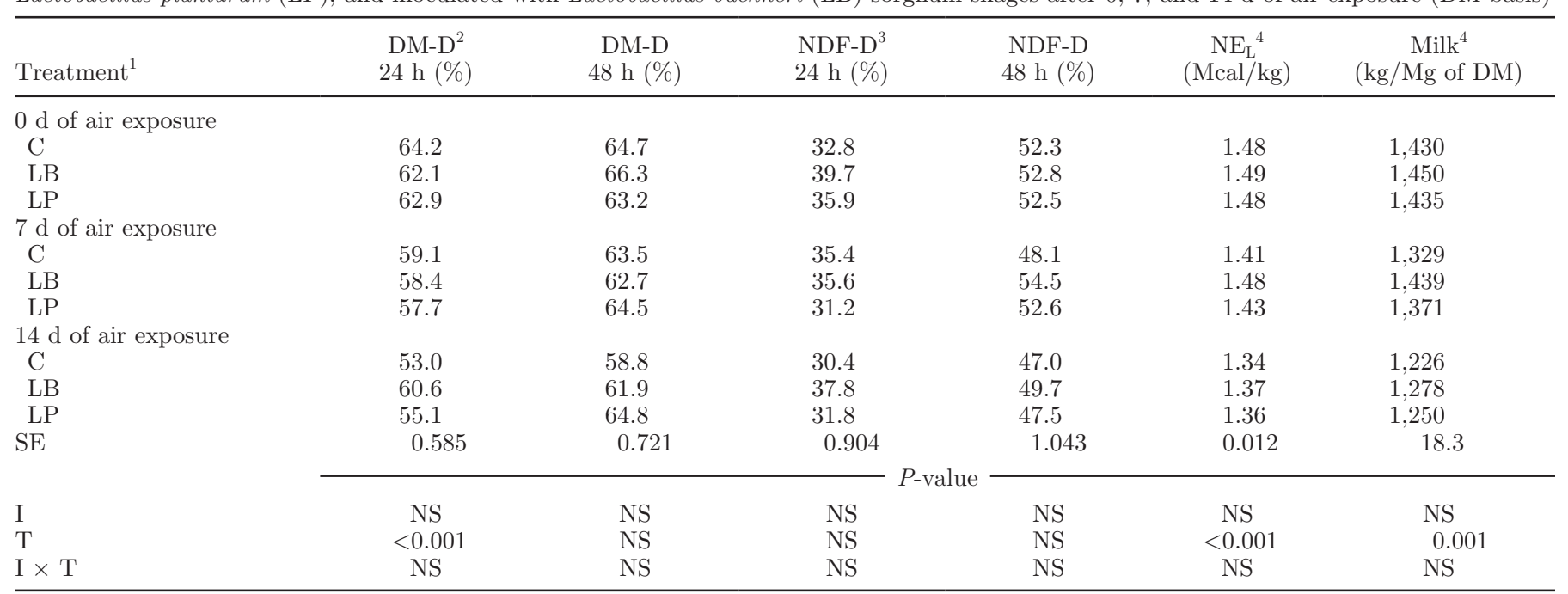

${ }^{1} \mathrm{I}=$ inoculum effect; $\mathrm{T}=$ air exposure time effect; $\mathrm{I} \times \mathrm{T}=$ interaction effect.

${ }^{2}$ In vitro DM digestibility.

${ }^{3}$ In vitro NDF digestibility.

${ }^{4}$ Estimations were made with MILK2006, using NDF-D $48 \mathrm{~h}$ as the default value. 
documented the effects of hybrid, maturity, mechanical processing, and particle size on the performance of lactating dairy cows fed whole crop corn and sorghum silage based rations and have emphasized the necessity of managing silage from harvesting to silo opening to maximize the amount of digestible DM harvested per hectare (Bal et al., 1997; Johnson et al., 2002; Schwab et al., 2003). The DM losses during ensiling were very low for both crops and treatments, resulting in a decrease of less than $5 \%$ of the energy contained in the fresh forage before ensiling. The L. buchneri inoculation did not affect the DMD-D or NDF-D at $48 \mathrm{~h}$ of the corn and sorghum silages at silo opening compared with those from the $\mathrm{C}$ and LP silages, as previously observed by Filya (2003) on low-DM corn and sorghum silages. Kang et al. (2009) found similar values of NDF degradability at 24 and $48 \mathrm{~h}$ for control and esteraseproducing L. buchneri strain-inoculated corn silages.

Because energy is the primary contribution of corn and sorghum silages to dairy cattle rations, its conservation during the feedout phase is important for diet formulation, milk production, and the net return of dairy farms. The exposure of silage to air during the feedout phase can initiate the aerobic spoilage process of the mass and the activity of lactate assimilating yeasts, which metabolize WSC and fermentation endproducts into carbon dioxide and water. This activity can also increase the temperature and $\mathrm{pH}$, and cause DM losses which reduce silage quality and digestibility (Woolford, 1990). Several studies on the aerobic deterioration of silages (McDonald et al., 1991; Bolsen et al. 1993; Muck et al., 2003) have emphasized the great losses that occur during aerobic deterioration due to air infiltration in the feedout phase, but few data are available that couple DM losses to nutritional losses (Whitlock et al., 2000; Chen and Weinberg, 2009). To better understand the role of air on the reduction of the nutritional value and DM losses of silage during aerobic deterioration, the silages were left to deteriorate in laboratory trials for up to $14 \mathrm{~d}$. This time period was chosen to represent the average age of silage in the peripheral areas of farm bunker silos at risk to air exposure when a feedout rate of 0.7 to $1.4 \mathrm{~m} /$ wk is adopted (Borreani and Tabacco, 2008; Weinberg et al., 2009), which results in a potential aerobic exposure of the silage of 20 to $10 \mathrm{~d}$.

In this experiment, the LB corn and sorghum silages had a fermentation profile that was modified with a greater level of acetic acid than that of the $\mathrm{C}$ and LP silages, and this was reflected in greater aerobic stability, due to the inhibition of yeast and mold growth during air exposure, as highlighted in Tabacco et al. (2009). These fermentation profiles and aerobic stability values are common when $L$. buchneri is used as a silage inoculant and are consistent with those observed

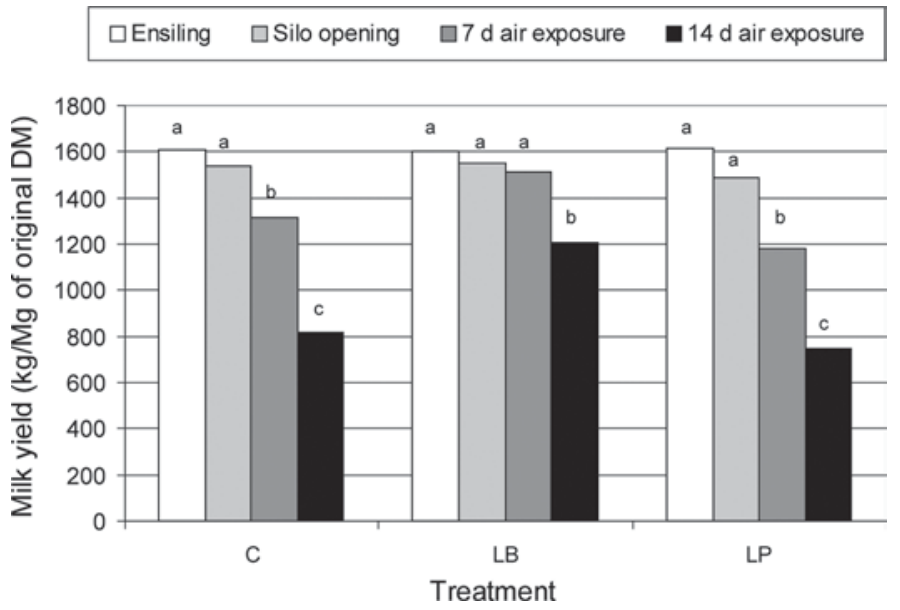

Figure 2. The estimated milk yield per megagram of pre-ensiled harvested DM of uninoculated (C), inoculated with Lactobacillus plantarum (LP), and inoculated with Lactobacillus buchneri (LB) corn silages after 0,7 , and $14 \mathrm{~d}$ of air exposure. The estimations were made with MILK2006. Within treatment, bars with different superscripts (a, b, or c) are significantly different at $P<0.05$.

by Filya et al. (2006) and $\mathrm{Hu}$ et al. (2009). On the other hand, several workers have found that inoculants containing homofermentative bacteria can predispose silages to aerobic deterioration because they result in relatively greater levels of residual WSC and lactic acid, which are used as growth substrate by spoilage-causing yeasts and molds (Huisden et al., 2009; Schmidt and Kung, 2010). In the first phases of deterioration, which occurred on average after $40 \mathrm{~h}$ of air exposure for $\mathrm{C}$ and LP silages, some easily oxidizable constituents of forage were quickly depleted and, as a consequence, the

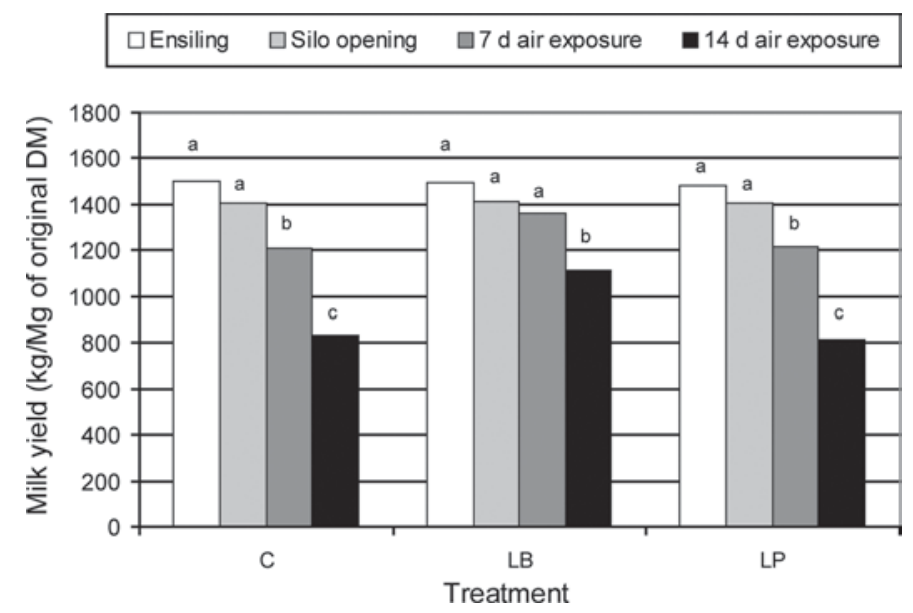

Figure 3. The estimated milk yield per megagram of pre-ensiled harvested DM of uninoculated (C), inoculated with Lactobacillus plantarum (LP), and inoculated with Lactobacillus buchneri (LB) sorghum silages after 0,7 , and $14 \mathrm{~d}$ of air exposure. The estimations were made with MILK2006. Within treatment, bars with different superscripts (a, b, or c) are significantly different at $P<0.05$. 
Table 7. Regression models of the estimated milk yield per megagram of pre-ensiled harvested DM of the corn (equations 1 and 3 ) and sorghum (equations 2 and 4) silages on the mold count (MOLD, $\log \mathrm{cfu} / \mathrm{g}$ ) and hourly accumulated temperature increase $\left(\mathrm{TCUM},{ }^{\circ} \mathrm{C}\right)$ used as independent variables

\begin{tabular}{|c|c|c|c|}
\hline Eq. no. & Equation model $^{1}$ & $\begin{array}{l}\text { Adjusted } \\
\mathrm{r}^{2} \text { or } \mathrm{R}^{2}\end{array}$ & $\begin{array}{l}\text { Root mean } \\
\text { square error }\end{array}$ \\
\hline 1 & Milk yield $(\mathrm{kg} / \mathrm{Mg}$ original $\mathrm{DM})=+1,541.2-8.524 \times \mathrm{MOLD}^{2}$ & 0.746 & 158.7 \\
\hline 2 & Milk yield $(\mathrm{kg} / \mathrm{Mg}$ original $\mathrm{DM})=+1,433.4-6.872 \times \mathrm{MOLD}^{2}$ & 0.800 & 110.8 \\
\hline 4 & Milk yield $(\mathrm{kg} / \mathrm{Mg}$ original $\mathrm{DM})=+1,379.3-0.178 \times \mathrm{TCUM}$ & 0.741 & 126.2 \\
\hline
\end{tabular}

${ }^{1}$ All coefficients are significantly different from zero $(P<0.05)$.

more complex structural carbohydrates, crude protein, and ash tended to increase on a DM basis. In more advanced stages of aerobic deterioration, the development of molds, which are capable of degrading complex carbohydrates such as starch, increase the bioavailability of WSC (up to 3.19 and $3.26 \%$ on the DM of the corn and sorghum C silages, respectively) and offer the possibility to other opportunistic aerobic microbes of proliferating and further aggravating the degradation of the silage mass (Pahlow et al., 2003). This was particularly evident after $14 \mathrm{~d}$ of air exposure, where the starch content decreased to 29 and $23 \%$ on the DM for corn and sorghum silages, respectively, regardless of the inoculum treatment. Unexpectedly, some starch degradation occurred in the LB corn and sorghum silages even though the aerobic deterioration process was at the beginning (less than $2 \mathrm{~d}$ from the increase in temperature) compared with that of the $\mathrm{C}$ and $\mathrm{LP}$ treatments, where the starch degradation had occurred after more than $5 \mathrm{~d}$ from the beginning of aerobic spoilage. The DM losses increased during aerobic deterioration in the $\mathrm{C}$ and LP silages and reached higher values than the 400 and $300 \mathrm{~kg} / \mathrm{Mg}$ of the original stored DM after $14 \mathrm{~d}$ of air exposure, for corn and sorghum, respectively. These DM losses are consistent with the values of up to $374 \mathrm{~kg} / \mathrm{Mg}$ reported by Borreani et al. (2007) for the peripheral areas of commercial farm silage, and by Ashbell and Lisker (1988), who reported
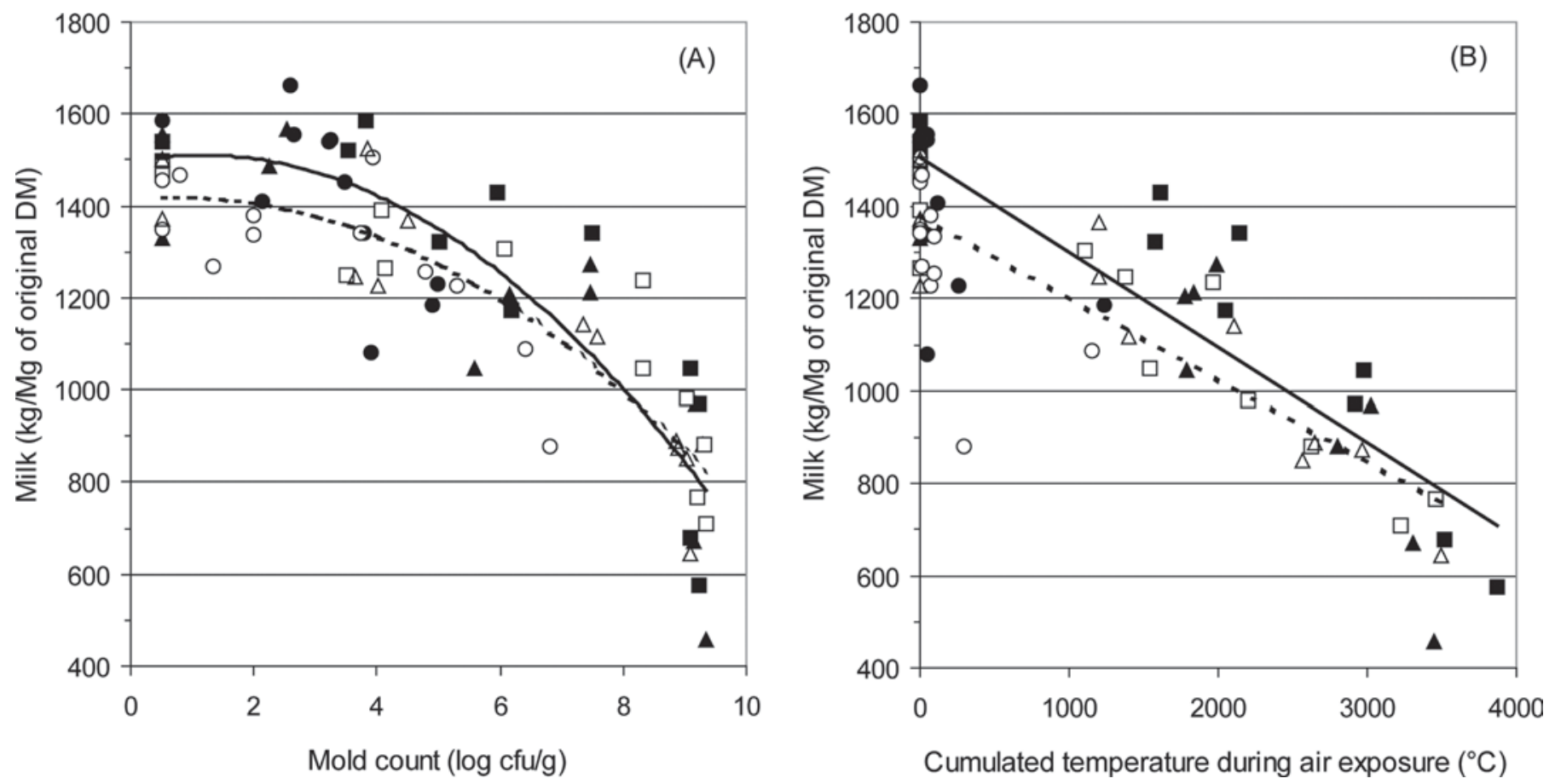

Figure 4. The estimated milk yield per megagram of pre-ensiled harvested DM of the corn and sorghum silages in relation to A) mold count and B) hourly accumulated temperature rise $\left({ }^{\circ} \mathrm{C}\right)$ above the ambient temperature over $14 \mathrm{~d}$ of air exposure. Full symbols, corn silage; empty symbols, sorghum silage; full regression lines, corn silages; dotted regression lines, sorghum silages; squares = uninoculated silage; circles = inoculated with Lactobacillus buchneri treatment; triangles = inoculated with Lactobacillus plantarum treatment. 
DM losses ranging from 102 to $358 \mathrm{~kg} / \mathrm{Mg}$ for corn silages in the upper layer and near the bunker walls. The LB treatment, which contrasted the development of yeasts due to the production of acetic acid and, thus, enhanced the aerobic stability of the ensiled forage crop, greatly reduced the DM losses, which remained below $150 \mathrm{~kg} / \mathrm{Mg}$ of the original stored DM, even after $14 \mathrm{~d}$ of air exposure, regardless of the crop. The DM losses and nutritional analysis data for the corn and sorghum herbage and silages at silo opening and after 7 and $14 \mathrm{~d}$ of air exposure were run through MILK2006 to estimate the potential milk production that could be obtained from $1 \mathrm{Mg}$ of original harvested DM. Inoculation with $L$. buchneri, at a rate of $1 \times 10^{6} \mathrm{cfu} g$ of fresh forage, showed the possibility of maintaining the potential milk yield of harvested forage for up to $7 \mathrm{~d}$ of air exposure, whereas a consistent decrease in the potential milk production already occurred after $7 \mathrm{~d}$ of air exposure in the $\mathrm{C}$ and LP silages.

When the estimated milk yields per megagram of harvested DM of corn and sorghum silage were related to the mold count, it was noted that the loss of potential milk production occurred when the mold development exceeded $4 \mathrm{log} \mathrm{cfu} / \mathrm{g}$ of silage, and it was almost halved when the mold count reached greater values than 8 log cfu/g of silage. Borreani and Tabacco (2010) reported that the mold count in visible molded corn silages, which had been collected in a farm survey, ranged from 5.7 to $9.4 \log \mathrm{cfu} / \mathrm{g}$ of the silage, with an average value of $8.0 \mathrm{log} \mathrm{cfu} / \mathrm{g}$. The same authors also reported that the mold count could exceed $6 \mathrm{log} \mathrm{cfu} / \mathrm{g}$ of silage in the peripheral areas of bunker silage, even when there were any visible moldy patches. The measured temperature of the silage in these areas showed higher values than $40^{\circ} \mathrm{C}$, which exceeded those of the stable center of the bunker by more than $20^{\circ} \mathrm{C}$.

In this experiment, the estimated milk yield decreased in a linear manner as the accumulated temperature above the ambient temperature increased. When an accumulated temperature of about $1,000^{\circ} \mathrm{C}$ was recorded, an average loss of $10 \%$ of the estimated milk yield was observed for both the corn and sorghum silages. When aerobic activity starts, due to the exposure of silage to air, the increase in temperature is very fast and can reach more than $45^{\circ} \mathrm{C}$ in a few hours, with a difference from the ambient temperature of more than $20^{\circ} \mathrm{C}$, which offers the possibility of accumulating more than $500^{\circ} \mathrm{C}$ each day. In this experiment, an accumulated temperature rise of $1,000^{\circ} \mathrm{C}$ corresponded to about 2 to $3 \mathrm{~d}$ of silage heating, whereas mold began to be visible after an accumulated temperature of at least $1,400^{\circ} \mathrm{C}$. This means that, when silage temperature begins to increase due to the activity of aerobic microorganisms, the nutritive values could decrease by as much as $16 \%$ of that of silage at opening before molds start to be visible. This decrease in nutritive value could mainly be due to the depletion of fermentation endproducts and oxidation of WSC, which progressively become available from starch and hemicellulose degradation.

The findings of this research show that substantial changes in nutritional quality occur when silage is exposed to air and when the decrease in nutritional quality is coupled to DM losses, a dramatic decrease occurs in the potential milk production of the original harvested crop. The results have also shown that the inoculation of corn and sorghum forages with $L$. buchneri at a rate of $1 \times 10^{6} \mathrm{cfu} / \mathrm{g}$ of fresh forage enhances the stability of silage after exposure to air, and, consequently, contributes to maintaining the nutritional value of the harvested forage over time, for up to $7 \mathrm{~d}$ of air exposure. These inoculation rates are higher than those commonly used on farms (from 1 to $3 \times 10^{5} \mathrm{cfu} / \mathrm{g}$ of fresh forage); thus, further research is necessary to assess the effectiveness of L. buchneri in enhancing aerobic stability and maintaining the nutritional value of silages at a farm level. The results showed that a cost benefit could be possible if the on farm inoculation rate would be increased to $1 \times 10^{6} \mathrm{cfu} / \mathrm{g}$ of fresh forage in the top layers of a bunker silo (last $50 \mathrm{~cm}$ ), which are those at greatest risk of aerobic spoilage. To the authors' knowledge, the experiment reported in this paper is the first attempt to correlate mold count and temperature of silage to nutritional quality losses and to the reduction in NDF-D and potential milk yield. Further research is necessary to quantify the extent of nutritional losses in commercial farm silos, related to the aerobic deterioration of silage, to silage temperature and to mold development.

\section{ACKNOWLEDGMENTS}

This work was funded by the Regione Piemonte, Assessorato Qualità, Ambiente e Agricoltura years 2005-2008 Project: "Influenza della zona di produzione e del tipo di gestione aziendale sulla qualità del Grana Padano D.O.P. piemontese." All of the authors contributed equally to the work described in this paper.

\section{REFERENCES}

Ashbell, G., and N. Lisker. 1988. Aerobic deterioration in maize silage stored in a bunker silos under farm conditions in a subtropical climate. J. Sci. Food Agric. 45:307-315.

Association of Official Analytical Chemists (AOAC). 2005. Official Methods of Analysis. 18th ed. AOAC, Washington, DC.

Bal, M. A., J. G. Coors, and R. D. Shaver. 1997. Impact of the maturity of corn for use as silage in the diets of dairy cows on intake, digestion, and milk production. J. Dairy Sci. 80:2497-2503.

Bolsen, K. K., J. T. Dickerson, B. E. Brent, R. N. Sonon Jr., B. S. Dalke, C. Lin, and J. E. Boyer Jr.. 1993. Rate and extent of top spoilage losses in horizontal silos. J. Dairy Sci. 76:2940-2962. 
Borreani, G., and E. Tabacco. 2007. Il silomais. Guida pratica. [A Practical Guide for Corn Silage Management]. Agricoltura e Ricerca, Regione Piemonte, L'Artistica Savigliano, Savigliano (CN), Italy.

Borreani, G., and E. Tabacco. 2008. Low permeability to oxygen of a new barrier film prevents butyric acid bacteria spore formation in farm corn silage. J. Dairy Sci. 91:4272-4281.

Borreani, G., and E. Tabacco. 2009. Quantifying the extent of aerobic deterioration in corn bunker and pile silages at a farm level. Pages 321-322 in Proc. 15th International Silage Conference, Madison, WI. US Dairy Forage Research Centre, USDA-ARS, Madison, WI.

Borreani, G., and E. Tabacco. 2010. The relationship of silage temperature with the microbiological status of the face of corn silage bunkers. J. Dairy Sci. 93:2620-2629.

Borreani, G., E. Tabacco, and L. Cavallarin. 2007. A new oxygen barrier film reduces aerobic deterioration in farm scale corn silage. J. Dairy Sci. 90:4701-4706.

Canale, A., M. E. Valente, and A. Ciotti. 1984. Determination of volatile carboxylic acids $(C 1-C 5)$ and lactic acid in aqueous acid extracts of silage by high performance liquid chromatography. J. Sci. Food Agric. 35:1178-1182.

Chen, Y., and Z. G. Weinberg. 2009. Changes during aerobic exposure of wheat silages. Anim. Feed Sci. Technol. 154:76-82.

Deriaz, R. E. 1961. Routine analysis of carbohydrates and lignin in herbage. J. Sci. Food Agric. 12:152-160.

Filya, I. 2003. The effect of Lactobacillus buchneri and Lactobacillus plantarum on the fermentation, aerobic stability, and ruminal degradability of low dry matter corn and sorghum silages. J. Dairy Sci. 86:3575-3581.

Filya, I. 2004. Nutritive value and aerobic stability of whole crop silage harvested at four stages of maturity. Anim. Feed Sci. Technol. 116:141-150.

Filya, I., E. Sucu, and A. Karabulut. 2006. The effect of Lactobacillus buchneri on the fermentation, aerobic stability and ruminal degradability of maize silage. J. Appl. Microbiol. 101:1216-1223.

Goering, H. K., and P. J. Van Soest. 1970. Forage fiber analyses (apparatus, reagents, procedures, and some applications). Agriculture Handbook No. 379, Agric. Res. Serv., USDA, Washington, DC.

Hu, W., R. J. Schmidt, E. E. McDonell, C. M. Klingerman, and L. Kung Jr.. 2009. The effect of Lactobacillus buchneri 40788 or Lactobacillus plantarum MTD-1 on the fermentation and aerobic stability of corn silages ensiled at two dry matter contents. J. Dairy Sci. 92:3907-3914.

Huisden, C. M., A. T. Adesogan, S. C. Kim, and T. Ososanya. 2009. Effect of applying molasses or inoculants containing homofermentative or heterofermentative bacteria at two rates on the fermentation and aerobic stability of corn silage. J. Dairy Sci. 92:690697.

Johnson, L. M., J. H. Harrison, D. Davidson, W. C. Mahanna, K. Shinners, and D. Linder. 2002. Corn silage management: Effects of maturity, inoculation, and mechanical processing on pack density and aerobic stability. J. Dairy Sci. 85:434-444.

Kang, T. W., A. T. Adesogan, S. C. Kim, and S. S. Lee. 2009. Effects of an esterase-producing inoculant on fermentation, aerobic stability, and neutral detergent fiber digestibility of corn silage. J. Dairy Sci. 92:732-738.

Kleinschmit, D. H., and L. Kung Jr.. 2006. A meta-analysis of the effects of Lactobacillus buchneri on the fermentation and aerobic stability of corn and grass and small-grain silages. J. Dairy Sci. 89:4005-4013.

Kung, L. Jr., B. M. Moulder, C. M. Mulrooney, R. S. Teller, and R. J. Schmidt. 2008. The effect of silage cutting height on the nutritive value of a normal corn silage hybrid compared with brown midrib corn silage fed to lactating cows. J. Dairy Sci. 91:1451-1457.

Kung, L. Jr., and N. K. Ranjit. 2001. The effect of Lactobacillus buchneri and other additives on the fermentation and aerobic stability of barley silage. J. Dairy Sci. 84:1149-1155.

Kung, L. Jr., A. C. Sheperd, A. M. Smagala, K. M. Endres, C. A. Bessett, N. K. Ranjit, and J. L. Glancey. 1998. The effect of pre- servatives based on propionic acid on the fermentation and aerobic stability of corn silage and a total mixed ration. J. Dairy Sci. 81:1322-1330.

Lauer, J., K. Kohn, and T. Diallo. 2009. Wisconsin corn hybrid performance trial results grain and silage. Accessed April 8, 2010 http://corn.agronomy.wisc.edu/HT/2009/2009HTSTBook.pdf

Lindgren, S., G. Pahlow, and E. Oldenburg. 2002. Influence of microbes and their metabolites on feed and food quality. Pages 503-511 in Proc. 19th Gen. Meet. EGF, La Rochelle, France. Br. Grassl. Soc., Reading, UK

Mari, L. J., R. J. Schmidt, L. G. Nussio, C. M. Hallada, and L. Kung Jr.. 2009. An evaluation of the effectiveness of Lactobacillus buchneri 40788 to alter fermentation and improve the aerobic stability of corn silage in farm silos. J. Dairy Sci. 92:1174-1176.

Marsalis, M. A., R. E. Kirksey, F. E. Contreras-Govea, L. Carrasco, M. K. O'Neill, L. M. Lauriault, and M. Place. 2009. New Mexico 2009: Corn and Sorghum Performance Tests. New Mexico State University, Las Cruces.

McDonald, P., A. R. Henderson, and S. J. E. Heron. 1991. The Biochemistry of Silage. 2nd ed. Chalcombe Publications, Bucks, UK.

Muck, R. E., I. E. Moser, and R. E. Pitt. 2003. Postharvest factors affecting ensiling. Pages 251-304 in Silage Science and Technology. Vol. 42. D. R. Buxton, R. E. Muck, and J. H. Harrison, ed. Am. Soc. Agron., Crop Sci. Soc. Am., and Soil Sci. Soc. Am., Madison, WI.

Oude Elferink, S. J. W. H., J. Krooneman, J. C. Gottschal, S. F. Spoelstra, F. Faber, and F. Driehuis. 2001. Anaerobic conversion of lactic acid to acetic acid and 1,2-propanediol by Lactobacillus buchneri. Appl. Environ. Microbiol. 67:125-132.

Pahlow, G., R. E. Muck, F. Driehuis, S. J. W. H. Oude Elferink, and S. F. Spoelstra. 2003. Microbiology of ensiling. Pages 31-93 in Silage Science and Technology. Vol. 42. D. R. Buxton, R. E. Muck, and J. H. Harrison, ed. Am. Soc. Agron., Crop Sci. Soc. Am., and Soil Sci. Soc. Am., Madison, WI.

Ranjit, N. K., and L. Kung Jr.. 2000. The effect of Lactobacillus buchneri, Lactobacillus plantarum, or a chemical preservative on the fermentation and aerobic stability of corn silage. J. Dairy Sci. 83:526-535.

Richard, E., N. Heutte, V. Bouchart, and D. Garon. 2009. Evaluation of fungal contamination and mycotoxin production in maize silage. Anim. Feed Sci. Technol. 148:309-320.

Robertson, J. B., and P. J. Van Soest. 1981. The detergent system of analysis and its application to human foods. Pages 123-158 in The Analysis of Dietary Fiber in Food. W. P. T. James and O. Theander, ed. Marcel Dekker, New York, NY.

Schmidt, R. J., and L. Kung Jr.. 2010. The effects of Lactobacillus buchneri with or without a homolactic bacterium on the fermentation and aerobic stability of corn silages made at different locations. J. Dairy Sci. 93:1616-1624.

Schwab, E. C., R. D. Shaver, J. G. Lauer, and J. G. Coors. 2003. Estimating silage energy value and milk yield to rank corn hybrids. Anim. Feed Sci. Technol. 109:1-18.

Shaver, R. D., J. G. Lauer, J. G. Coors, and P. C. Hoffman. 2006. MILK2006 Corn Silage: Calculates TDN-1x, NEL-3x, Milk per ton, and Milk per acre. Milk2006corn silagev1.xls. Accessed April 14, 2010. http://www.uwex.edu/ces/dairynutrition/spreadsheets. $\mathrm{cfm}$

Tabacco, E., S. Piano, L. Cavallarin, T. F. Bernardes, and G. Borreani. 2009. Clostridia spore formation during aerobic deterioration of maize and sorghum silages as influenced by Lactobacillus buchneri and Lactobacillus plantarum inoculants. J. Appl. Microbiol. 107:1632-1641.

Weinberg, Z. G., Y. Chen, and R. Solomon. 2009. The quality of commercial wheat silages in Israel. J. Dairy Sci. 92:638-644.

Whitlock, L. A., T. Wistuba, M. K. Siefers, R. V. Pope, B. E. Brent, and K. K. Bolsen. 2000. Effect of level of surface-spoiled silage on the nutritive value of corn silage-based rations. J. Dairy Sci. 83(Suppl. 1):110. (Abstr.)

Woolford, M. K. 1990. The detrimental effect of air on silage. J. Appl. Bacteriol. 68:101-116. 